Erratum

\title{
Erratum to "New Insights into Ligand-Receptor Pairing and Coevolution of Relaxin Family Peptides and Their Receptors in Teleosts"
}

\author{
Sara Good, ${ }^{1}$ Sergey Yegorov, ${ }^{1}$ Joran Martijn, ${ }^{2}$ Jens Franck, ${ }^{1}$ and Jan Bogerd ${ }^{2}$ \\ ${ }^{1}$ Department of Biology, University of Winnipeg, Winnipeg, MB, Canada R3B 2E9 \\ ${ }^{2}$ Department of Biology, Faculty of Science, University of Utrecht, $3584 \mathrm{CH}$ Utrecht, The Netherlands \\ Correspondence should be addressed to Sara Good; s.good@uwinnipeg.ca \\ Received 18 February 2013; Accepted 5 March 2013
}

Copyright (C) 2013 Sara Good et al. This is an open access article distributed under the Creative Commons Attribution License, which permits unrestricted use, distribution, and reproduction in any medium, provided the original work is properly cited.

The authors would like to make the following correction. In Figure 8, the bars for the $\operatorname{rxf} p$ genes, $r x f p 2 a$ and $r x f p 2 b$, were incorrectly labeled. This figure should be replaced by the following figure. The previous legend of Figure 8 is correct. 
Male heart

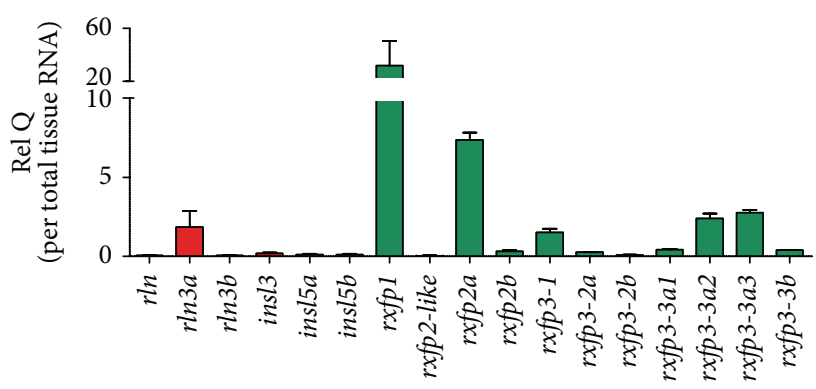

(a)

Male intestine

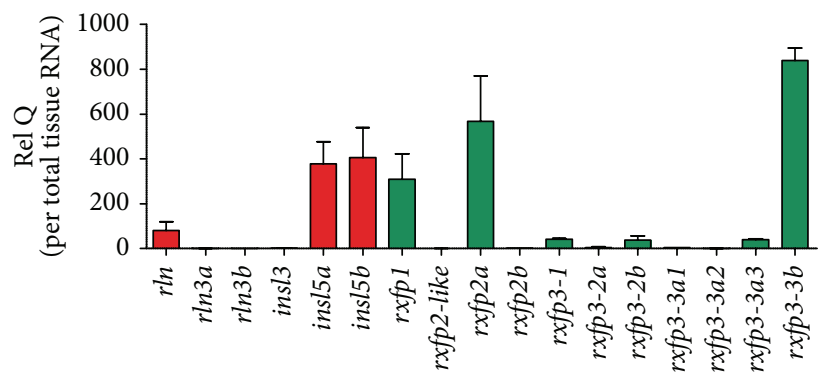

(c)

Male gills

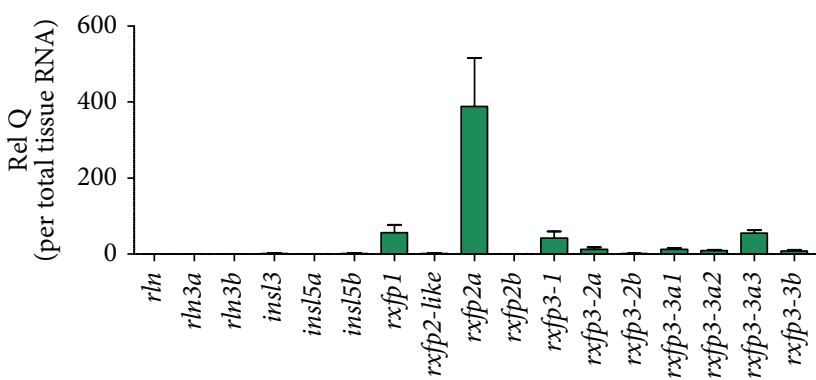

(e)

Male brain

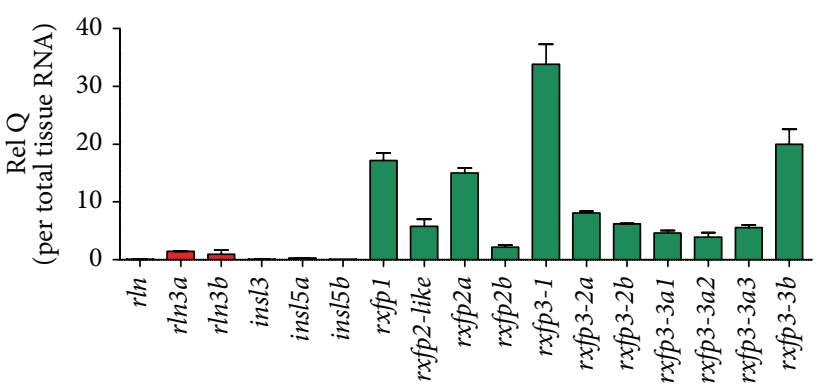

(g)
Female heart

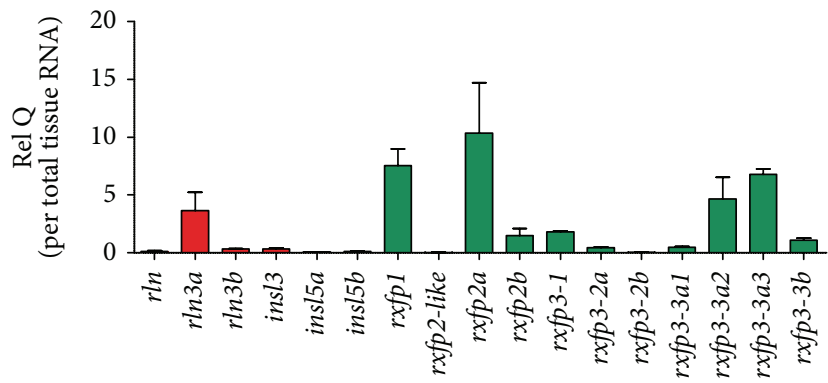

(b)

Female intestine

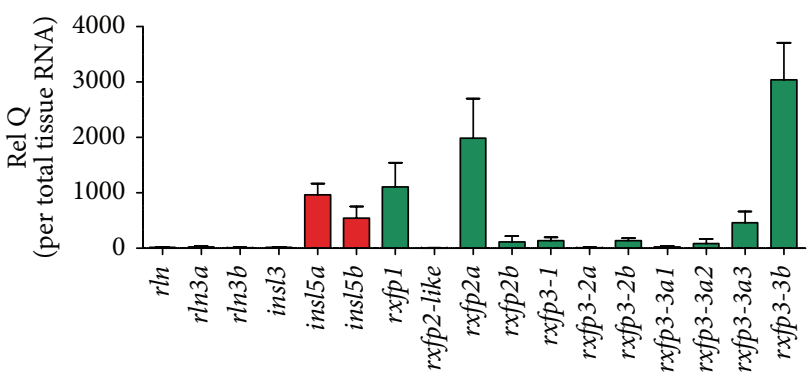

(d)

Female gills

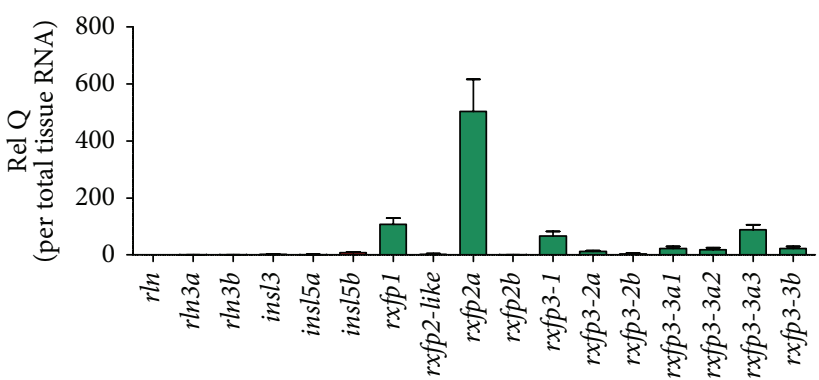

(f)

Female brain

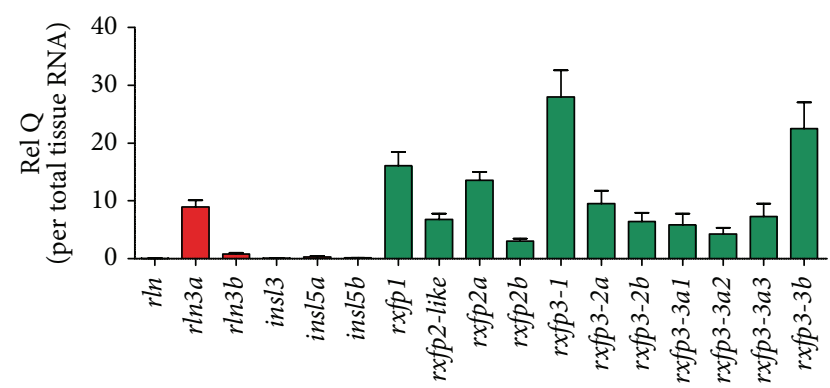

(h)

FIgUre 8: Continued. 
Male eyes

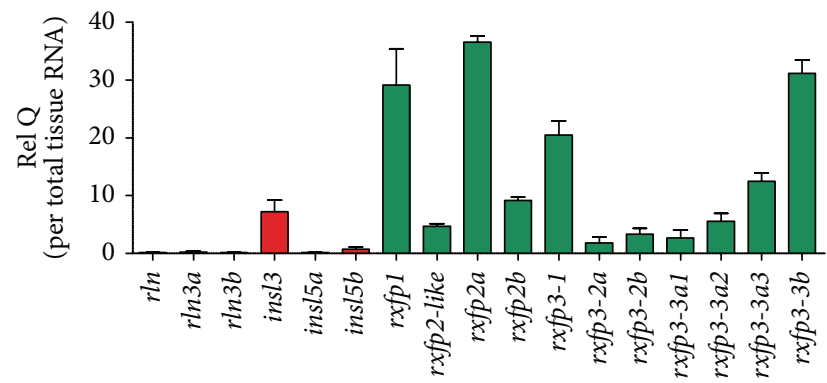

(i)

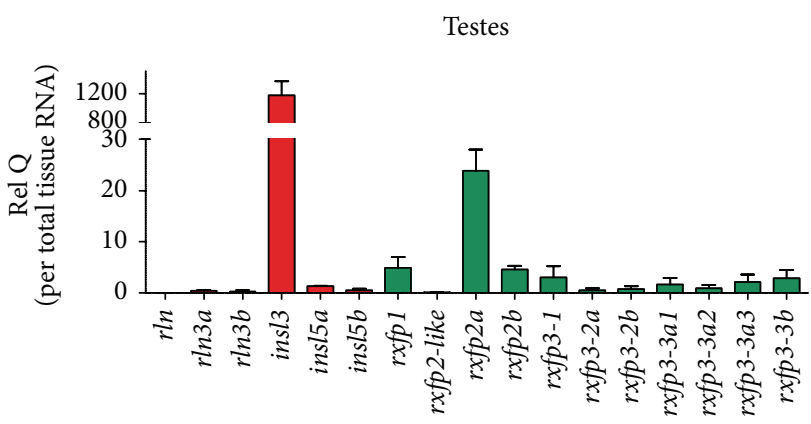

(k)
Female eyes

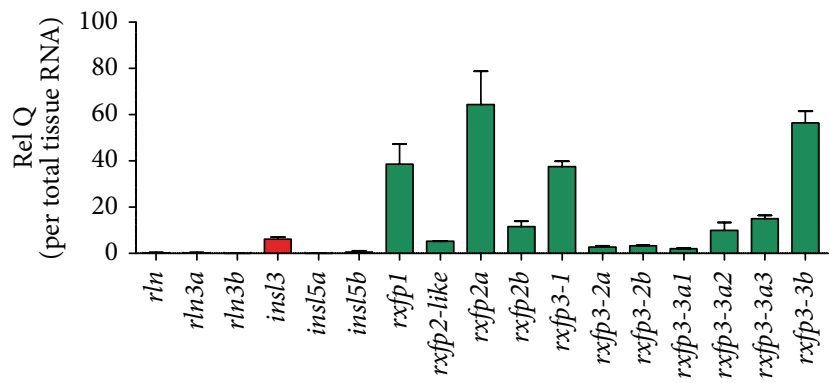

(j)

Ovaries

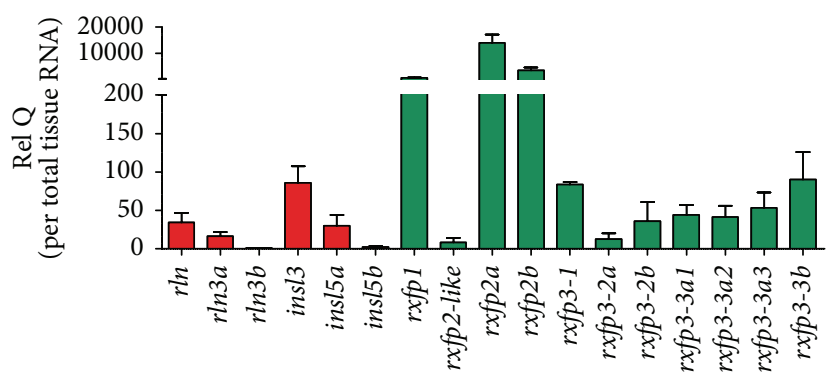

(1)

FIGURE 8: Relative expression of $r l n / i n s l$ and $r x f p$ genes in zebrafish tissues. The expression of a gene relative to the average expression across all genes in a given tissue of males and females is shown. Red and green bars indicate the relative expression of the ligand and receptor genes, respectively. Three biological replicates were used to determine the standard errors on the relative expression. 

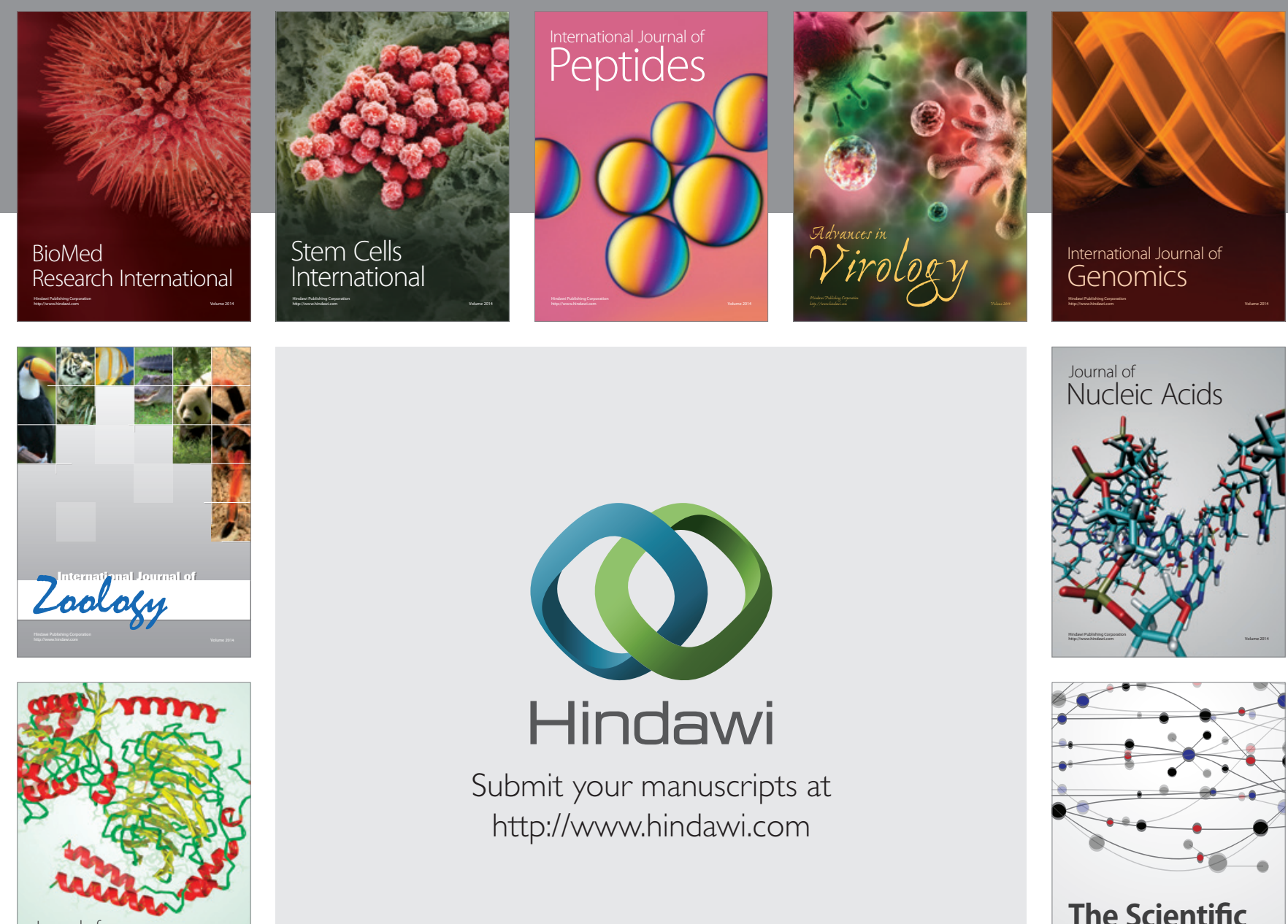

Submit your manuscripts at

http://www.hindawi.com

Journal of
Signal Transduction
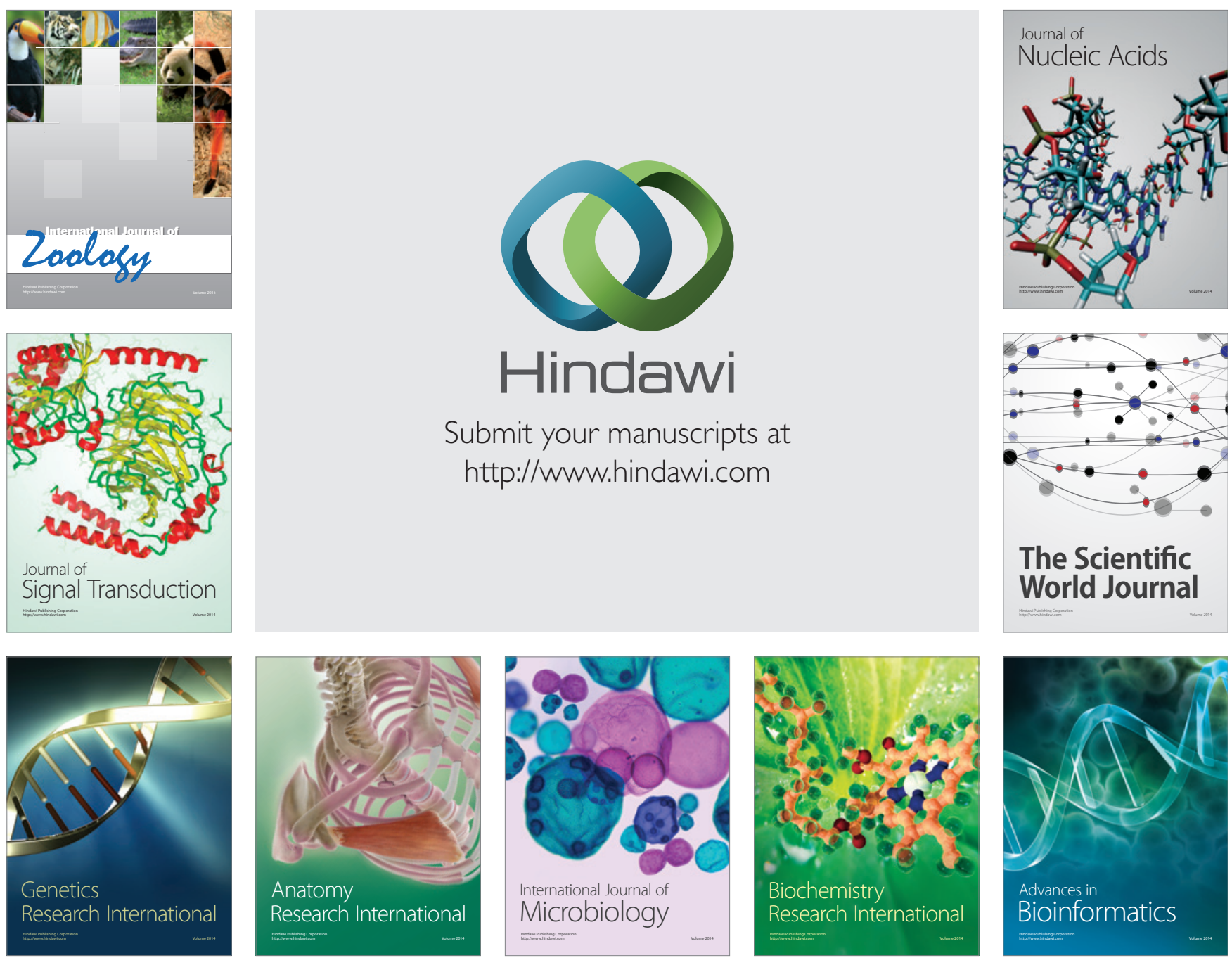

The Scientific World Journal
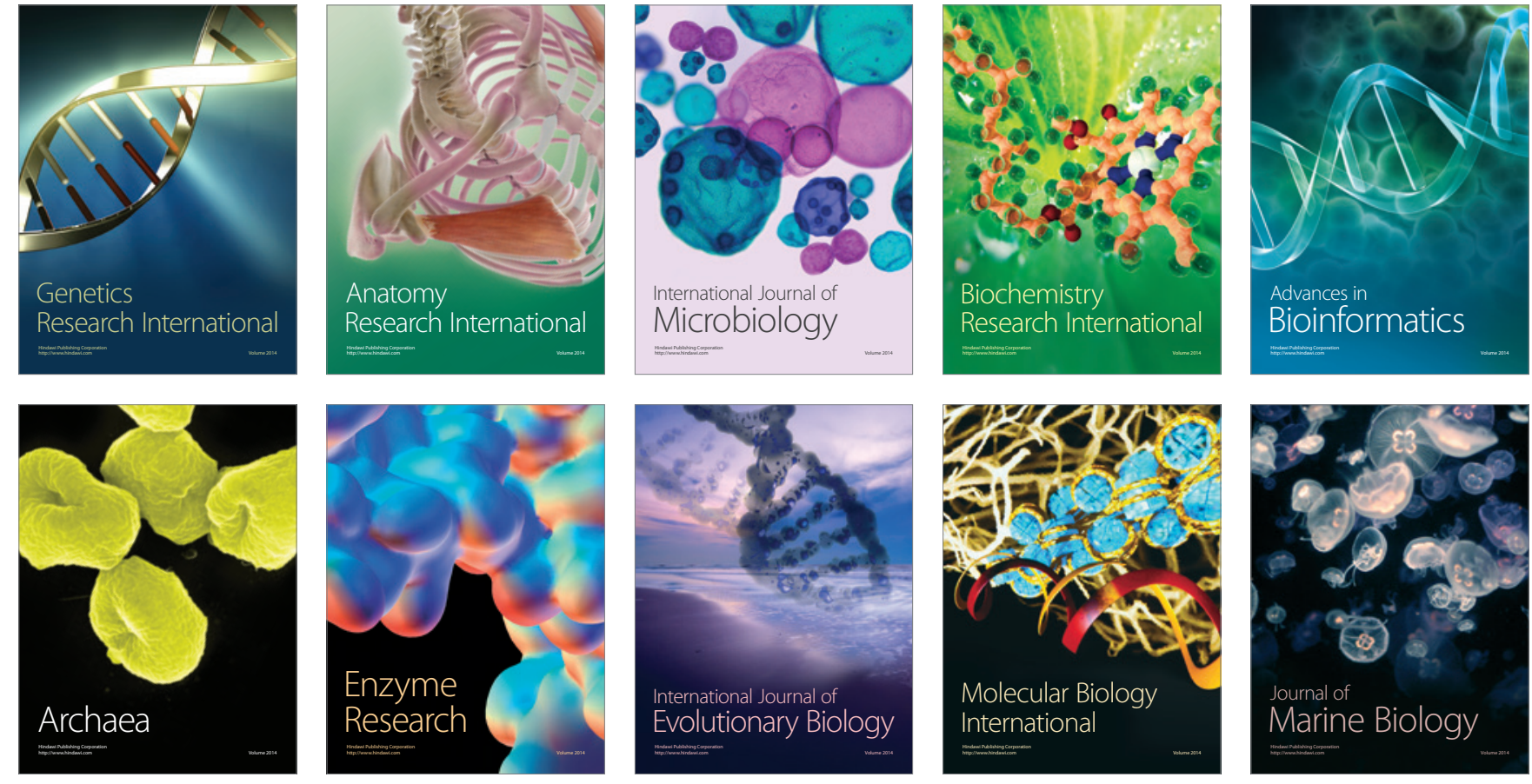